\title{
A Theory on Urban Resilience to Floods-A Basis for Alternative Planning Practices
}

\author{
Kuei-Hsien Liao $^{1}$
}

\begin{abstract}
River cities require a management approach based on resilience to floods rather than on resistance. Resisting floods by means of levees, dams, and channelization neglects inherent uncertainties arising from human-nature couplings and fails to address the extreme events that are expected to increase with climate change, and is thereby not a reliable approach to long-term flood safety. By applying resilience theory to address system persistence through changes, I develop a theory on "urban resilience to floods" as an alternative framework for urban flood hazard management. Urban resilience to floods is defined as a city's capacity to tolerate flooding and to reorganize should physical damage and socioeconomic disruption occur, so as to prevent deaths and injuries and maintain current socioeconomic identity. It derives from living with periodic floods as learning opportunities to prepare the city for extreme ones. The theory of urban resilience to floods challenges the conventional wisdom that cities cannot live without flood control, which in effect erodes resilience. To operationalize the theory for planning practice, a surrogate measure - the percent floodable area-is developed for assessing urban resilience to floods. To enable natural floodplain functions to build urban resilience to floods, flood adaptation is advocated in order to replace flood control for mitigating flood hazards.
\end{abstract}

Key Words: flood adaptation; flood control; flood hazard management; resilience-based management; resilience surrogate; resilient cities; urban floodplains; urban resilience

\section{INTRODUCTION}

Flood hazards challenge river cities around the world, despite many of them being protected by extensive flood-control infrastructures, such as levees, dams, and channelization. The twenty-first century has already seen large-scale flood disasters in Bangkok, Thailand (2011); Brisbane, Australia (2011); Guangdong, China (2007); New Orleans, USA (2005); Dresden, Germany (2002); and Taipei, Taiwan (2001), among others. The industrialized world has heavily relied on flood control to mitigate flood hazards, yet it is criticized for harming riverine ecosystems and increasing long-term flood risk (Burby et al. 2000, Smits et al. 2006). Alternative management concepts have emerged, emphasizing the integration between land and water management and of structural and nonstructural measures (e.g., Schneidergruber et al. 2004, Associated Programme on Flood Management 2009). Nevertheless, scholars continue to assert the indispensability of floodcontrol infrastructure for cities (e.g., Birkland et al. 2003, Godschalk 2003), which reflects the entrenched management paradigm of controlling nature.

Designed and operated under an obsolete assumption that the pattern of flow variability remains unchanged over time (Milly et al. 2008), flood-control infrastructure is not a reliable mitigation approach in the face of climate change uncertainties (Zevenbergen and Gersonius 2007). Cities that depend on flood-control infrastructure can resist floods only up to a certain magnitude, thereby these cities are ill-prepared for capacity-exceeding extreme floods, which are expected to increase with more intense storms whose exact natures are unpredictable (Alley et al. 2007). An alternative mitigation approach is needed, which this paper addresses by developing a flood hazard management concept that focuses on resilience.

The idea of resilience has a long history in ecology and engineering, but its application to natural hazard management is relatively recent (Berkes 2007). What defines resilience to floods remains ambiguous, despite the increasing attention given to the concept of resilience in flood hazard management. In this paper I address urban built environment and riverine flooding to develop a theory on "urban resilience to floods". There are two major resilience interpretations-engineering resilience and ecological resilience (Holling 1996). I explain why the latter is a more appropriate theoretical framework for management and for defining urban resilience to floods. In order to operationalize the theory for planning practices, a resilience surrogate measure is proposed for assessing urban resilience to floods. The theory and the measure together indicate that flood adaptation should replace flood control in order to build urban resilience to floods.

\section{INTERPRETATIONS OF RESILIENCE}

Engineering resilience and ecological resilience are two distinct interpretations (Holling 1996). Discerning their fundamental differences is important because they lead to divergent problem definitions, focuses, and approaches when applied to flood hazard management. 


\section{Engineering resilience and ecological resilience}

In engineering, resilience is concerned with disturbances that threaten the functional stability of engineering systems, which are often linked with low probabilities of failures or, in the case of failure, quick recovery to normal levels of functionality (Wang and Blackmore 2009). Such resilience depends on four properties: robustness, or the physical strength to withstand a disturbance without functional degradation; redundancy, or the extent to which system components are substitutable; resourcefulness, or the capacity to identify problems and mobilize needed resources; and rapidity, or the capacity to restore the system in a timely manner (Bruneau et al. 2003). This engineering resilience concept encompasses both resistance to and recovery from disturbances, although the measurement is focused exclusively on recovery-the faster the full functionality is restored, the greater the resilience (for example, Hashimoto et al. 1982, Hollnagel et al. 2008, Fig. 1). Engineering resilience thus emphasizes the ability to bounce back to the original condition when relaxed from stress (Wang and Blackmore 2009).

Fig. 1. A conceptual representation of engineering resilience, modified after Wang and Blackmore (2009). Resilience of a damaged system is measured by the time it takes ( $\mathrm{t} 1-\mathrm{t} 0$ for Case A) for the system to recover to $100 \%$ of its previous functionality. The longer it takes, the less resilient the system is (Case $\mathrm{B}$ ).

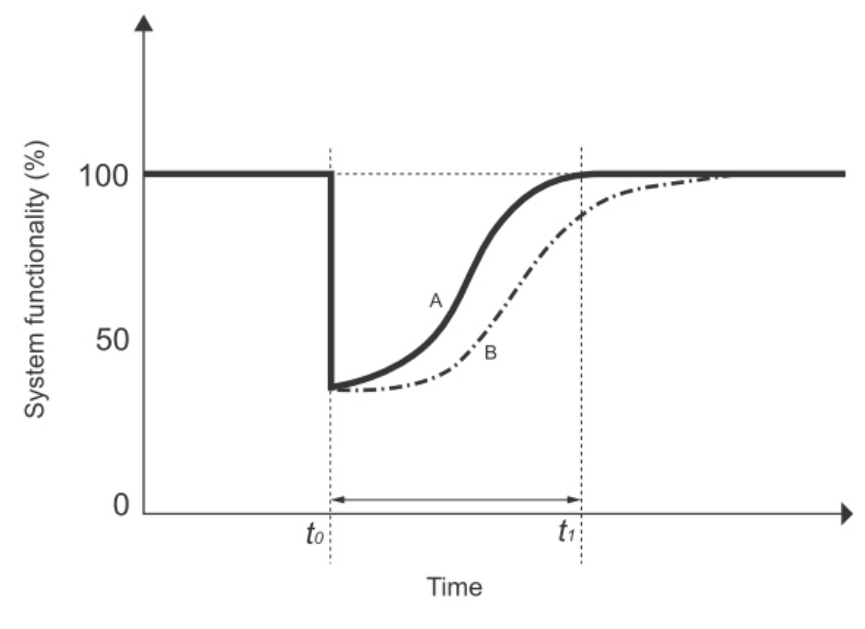

In ecology, Holling (1973) introduces the term resilience to describe observed ecosystem dynamics. It challenges the conventional ecological paradigm of equilibrium that assumes a predetermined stable state for every ecosystem, to which it eventually returns after a disturbance. Empirical studies show that some ecosystems never stabilize due to frequent disturbances. Multi-equilibria also exist when the ecosystem stabilizes after a disturbance but in a different state. It means the ecosystem is characterized by a different set of structures and processes, and returning to the previous ecosystem is extremely difficult if not impossible (Holling 1973, Scheffer et al. 2001). Building on the alternative paradigm of multiequilibria/nonequilibrium, Holling (1973) defines resilience as the system's ability to absorb disturbances and still persist. This ecological resilience concept focuses on persistence, or remaining within the same regime defined by the same processes, structures, feedbacks, and identity (Walker et al. 2004). Because systems do not operate near equilibrium, resilience is associated with the change the system can tolerate and the ability to reorganize or renew (Carpenter et al. 2001). It is measured by the magnitude of the disturbance the system can undergo before shifting to a different regime (Gunderson and Holling 2002).

In addressing different types of systems, several disparities exist between engineering and ecological resilience (Table 1). They derive mainly from the different assumptions of system dynamics regarding the number of possible regimes (Holling 1996, Fig. 2). The assumption behind engineering resilience, which is about maintaining the optimal state of functionality, is congruent with the ecological paradigm of equilibrium, presuming only one regime with an idealized stable state as the norm. The paradigmatic divergence reflects different perceptions towards normalcy. In the engineering resilience concept any change from the optimal state is deviant, while in the ecological resilience concept any fluctuation within the regime is normal because systems are inherently dynamic (Holling 1973).

Essentially, engineering resilience is the ability to maintain stability-remaining unchanged in system state or having minimum fluctuation; whereas ecological resilience is the ability to survive, regardless of the state. They are two different, even contradictory, system properties. Systems with high engineering resilience may have low ecological resilience; low engineering resilience may introduce high ecological resilience (Holling 1973, 1996).

\section{Community resilience to natural hazards}

The two resilience concepts receive increasing attention in hybrid systems, such as social-ecological systems (e.g., Berkes and Folke 1998) and socio-technical systems (e.g., Hollnagel et al. 2008). In natural hazard management, which deals with the interaction between humans and environmental fluctuations (Mileti 1999), engineering resilience prevails in current definitions of community resilience. Few authors define it without implying an optimal reference state, and it is frequently viewed as the capacity to withstand and recover quickly from disasters (Table 2). For example, Birkland and Waterman (2009) propose three features of community resilience-damage prevention, speedy recovery, and preservation of community functionality-arguing that the more stresses the community can bear to preserve functionality, the faster the recovery is. 
Table 1. Differences between engineering resilience and ecological resilience.

\begin{tabular}{|c|c|c|}
\hline & Engineering resilience & Ecological resilience \\
\hline Theoretic construct & Resilience $=$ resistance + recovery & Resilience $=$ tolerance + reorganization \\
\hline \multirow[t]{2}{*}{ Assumption } & One equilibrium (one regime) & Multiple equilibria (multiple regimes) \\
\hline & Predictability & Unpredictability and uncertainty \\
\hline Concerns & $\begin{array}{l}\text { Deviation from the ideal level of system functionality or } \\
\text { stable state }\end{array}$ & Regime shift \\
\hline Focus & Stability/consistency—returning quickly to the equilibrium & Persistence-remaining within the current regime \\
\hline Measurement & The speed of recovery to the previous stable state & $\begin{array}{l}\text { The magnitude of disturbance the system can undergo before } \\
\text { shifting to a different regime }\end{array}$ \\
\hline Disturbance role & Disturbances as threats & Disturbances as learning opportunities \\
\hline
\end{tabular}

Fig. 2. The paradigmatic difference between engineering and ecological resilience can be illustrated by the ball-andcup heuristic (Scheffer et al. 1993, Walker et al. 2004). The cup represents the region in the state space or "basin of attraction", in which the system tends to remain, and includes all possible values of system variables of interest. The ball represents the state of the system at any given time. The engineering resilience concept assumes only one regime, hence only one possible basin of attraction; and the very bottom of the basin represents the ideal stable state. The ecological resilience concept assumes multiple regimes, hence more than one basin of attraction. The system may move about within the basin, never settling at the bottom; it may also cross a threshold and settle in a new basin of attraction. The notion of engineering resilience is concerned with whether the system can remain at the bottom of the basin; while the notion of ecological resilience is concerned with whether the system can remain within the current basin (Holling 1996).
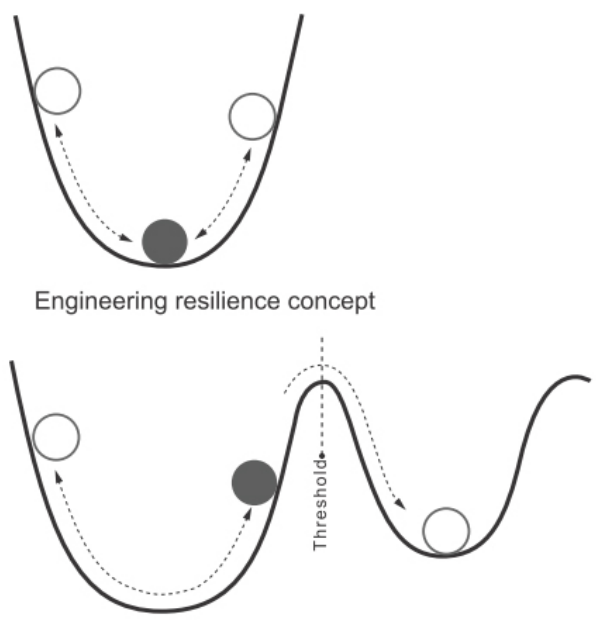

Ecological resilience concept
Discussions on community resilience place an overwhelming emphasis on recovery (e.g., Vale and Campanella 2005, Lamond and Proverbs 2009). In many cases, resilience is taken to mean exclusively the capacity to bounce back to the predisaster state, to differentiate from resistance, which means the ability to withstand a disturbance without disruption (e.g., Etkin 1999). In flood hazard management, for example, resistance means flood prevention by flood-control infrastructure, while resilience is the rate of return from a flood-impacted state to the normal one (De Bruijn 2004).

\section{ECOLOGICAL RESILIENCE AS THE THEORETICAL FRAMEWORK}

Applying the engineering resilience concept to communities that are subject to natural hazards is fundamentally problematic because of the outdated equilibrium paradigm. Recovery is often interpreted as returning to predisaster conditions, implicitly assuming an optimal reference state, which nevertheless does not exist in coupled human-natural systems (Berkes 2007). Urbanized floodplains are such systems, where climate, socioeconomic trends, built systems, and riverine processes affect flood hazards and disasters. They operate like evolving ecosystems rather than engineering systems and are characterized by complex behaviors associated with nonlinearity, emergence, uncertainty, and surprise (Liu et al. 2007). Such dynamic systems will not stay at a predetermined state. To be sure, moving quickly from a chaotic state to an organized one after a disaster is paramount, but it is unconstructive to restore the predisaster socioeconomic activities and built environments that are vulnerable in the first place (Klein et al. 2003). What remains unchallenged in this recovery notion is the preoccupation with stability. Stability becomes problematic when forced at temporal and spatial scales, at which the system is inherently dynamic (Cumming et al. 2006).

The ecological resilience concept is a more appropriate framework for flood hazard management, for it builds on a more realistic paradigm of multi-equilibria, focusing pragmatically on persistence in a world of flux (Adger et al. 2005). Thanks to studies on integrated social-ecological systems (e.g., Berkes et al. 2003), the ecological resilience 
Table 2. Some existing definitions of community resilience that are akin to engineering resilience.

\begin{tabular}{|c|c|}
\hline Definition of resilience & Reference \\
\hline $\begin{array}{l}\text { Sustainable and resilient communities are defined as societies that are structurally organized to minimize the effects } \\
\text { of disasters, and at the same time have the ability to recovery quickly by restoring the socioeconomic vitality of the } \\
\text { community. }\end{array}$ & Tobin (1999:13) \\
\hline $\begin{array}{l}\text { Resilience is the capacity to prevent or mitigate losses and then, if damage does occur, to maintain normal living } \\
\text { conditions as far as possible, and to manage recovery from the impacts. }\end{array}$ & Buckle et al. (2000:13) \\
\hline $\begin{array}{l}\text { Resilient cities are capable of withstanding severe shock without incurring either immediate chaos or permanent } \\
\text { damage, and of recovering from the impacts of natural hazards. }\end{array}$ & Godschalk (2003:136) \\
\hline $\begin{array}{l}\text { A resiliently built environment should be designed, located, built, operated, and maintained in ways that maximize } \\
\text { the ability of built assets, associated support systems (physical and institutional), and the people that reside or work } \\
\text { within the built assets to withstand, recover from, and mitigate the impacts of extreme natural and human-induced } \\
\text { hazards. }\end{array}$ & Bosher (2008:13) \\
\hline $\begin{array}{l}\text { The notion of resilience encompasses predisaster planning and warning systems, emergency handling procedures, } \\
\text { and postdisaster reconstruction. Urban resilience encompasses the idea that towns and cities should be able to } \\
\text { recover quickly from major and minor disasters. }\end{array}$ & Lamond and Proverbs (2009:63) \\
\hline
\end{tabular}

concept has become a sophisticated resilience theory, addressing complex human-nature couplings. It is instrumental for addressing flood hazards that arise from the interaction between riverine and urban dynamics.

\section{From maintaining stability to building resilience}

Two key arguments in resilience theory would shift the paradigm of flood hazard management. First, resilience arises from adapting to inherent variability, uncertainty, and surprise (Folke 2003). Coupled human-natural systems lose resilience when the inherent variability is artificially suppressed to promote stability through command-and-control management (Holling and Meffe 1996, Holling et al. 2002). This suggests that forcing floodplains to be inundation-free and building socioeconomic functionality upon forced environmental stability results in resilience erosion. It thus challenges the bias towards maintaining a dry floodplain and steady socioeconomic activities. Flood hazard management based on resilience theory would begin with acknowledging periodic floods as inherent environmental dynamics, by which socioeconomic activities on floodplains are inevitably affected.

Secondly, resilience theory holds that periods of gradual development and sudden changes complement each other (Folke 2006). As demonstrated in frequently disturbed ecosystems, resilience is borne out of experiencing and learning from disturbances (Holling 1973, Gunderson and Holling 2002). Research into communities relying on natural resources also indicates that resilience to large, unpredictable disturbances derives from allowing smaller ones to enter the system (Berkes and Folke 1998, Berkes et al. 2003). It suggests that flooding itself is an agent for resilience because each flood experience creates a chance for cities to adjust internal structures and processes and to build knowledge, leading to diverse coping strategies cumulated over time (Folke 2006, Smit and Wandel 2006). This contrasts with the attitude toward floods as being threatening, idiosyncratic events that legitimize flood control. As flood-control infrastructure prevents most floods, cities only learn painfully from rare, catastrophic ones with high prices. In the resilience-based flood hazard management, periodic floods are learning opportunities for cities to become better fit for extreme floods.

Overall, resilience theory suggests a paradigm shift in flood hazard management that should focus on building resilience as opposed to maintaining stability. Because flooding is inherently a part of the normal urban dynamics, resilience is neither flood resistance nor recovery to predisaster conditions —both are simply means to an end of stability. Here, resilience is the tendency to survive, which is itself an end.

\section{URBAN RESILIENCE TO FLOODS}

Two issues must be confronted before building the theory of urban resilience to floods based on resilience theory that originates in ecology. The resilience of ecological systems is concerned with system collapse; yet such a concern for cities is almost irrelevant, as history shows that most cities that have experienced catastrophic destructions have persisted and even flourished (Vale and Campanella 2005). A city remaining as a city means little to those who have lost their lives and to those forced into permanent hardship (Klein et al. 2003). Moreover, individual people matter in hazard management, although individual creatures are irrelevant to ecological systems that build resilience through system-level adaptation where less-fit individuals are continuously replaced (Gunderson 2010). Thus, urban resilience to floods encompasses dual concerns: the flood safety of individual citizens and the maintenance of the city's current identity.

\section{A definition}

Resilience theory has been applied to community resilience, stressing the capacity to absorb recurrent hazard impacts and reorganize while undergoing change so as to maintain fundamental structures, processes, identity, and feedbacks (Table 3). Likewise, urban resilience to floods is defined as 
Table 3. Some existing definitions of community resilience, without emphasizing recovery.

\begin{tabular}{|c|c|}
\hline Definition of resilience & Reference \\
\hline $\begin{array}{l}\text { The resilience of the coast is its self-organizing capacity to preserve actual and potential functions under changing } \\
\text { hydraulic and morphological conditions. }\end{array}$ & Klein et al. (1998:263) \\
\hline $\begin{array}{l}\text { Resiliency is the ability to withstand an extreme natural event without suffering devastating losses, damage, } \\
\text { diminished productivity, or quality of life, and without a large amount of assistance from outside the community. }\end{array}$ & Mileti (1999:32-33) \\
\hline $\begin{array}{l}\text { Resilience is the ability of an actor to cope with or adapt to hazard stress. It is a product of the degree of planned } \\
\text { preparation undertaken in the light of potential hazard, and of spontaneous or premeditated adjustments made in } \\
\text { response to felt hazard, including relief and rescue. }\end{array}$ & Pelling (2003:48) \\
\hline $\begin{array}{l}\text { Resilience is the capacity of linked social-ecological systems to absorb recurrent disturbances such as hurricanes or } \\
\text { floods so as to retain essential structures, processes, and feedbacks. }\end{array}$ & Adger et al. (2005:1036) \\
\hline $\begin{array}{l}\text { Disaster resilience could be viewed as the intrinsic capacity of a system, community, or society that is predisposed to } \\
\text { a shock or stress to adapt and survive by changing its nonessential attributes and rebuilding itself. }\end{array}$ & Manyena (2006:446) \\
\hline $\begin{array}{l}\text { Resilience is the capacity of a system to absorb disturbance and reorganize while undergoing change so as to still } \\
\text { retain essentially the same function, structure, identity, and feedbacks. }\end{array}$ & Berkes (2007:284) \\
\hline $\begin{array}{l}\text { A resilient system is able to absorb hazard impacts without changing its fundamental functions; at the same time, it is } \\
\text { able to renew, reorganize, and adapt when hazard impacts are significant. }\end{array}$ & $\begin{array}{l}\text { López-Marrero and Tschakert } \\
(2011: 230)\end{array}$ \\
\hline
\end{tabular}

the capacity of the city to tolerate flooding and to reorganize should physical damage and socioeconomic disruption occur, so as to prevent deaths and injuries and maintain current socioeconomic identity. It can be conceptualized as the capacity to remain in a desirable regime while experiencing a flood. The desirable regime is defined by a set of variables reflecting aspects such as livelihood security, economic performance, and mobility that collectively represent the city's socioeconomic identity (Adger 2000, Cumming et al. 2005, Gunderson 2010). Urban resilience to floods is measured by the flood magnitude the city can undergo until it reaches a threshold and shifts to an undesirable regime.

Unlike that for biophysical systems, a regime is socially rather than scientifically defined. The desirable regime reflects the city's tolerable range of socioeconomic state changes, which matters to urban resilience to floods (Fig. 3). A wider range implies that the city considers a greater degree of socioeconomic fluctuations normal, hence a larger/deeper basin of attraction; whereas a narrow range leads to a smaller/ shallow basin of attraction, and a flood could cause a regime shift easier (Carpenter et al. 2001, Walker et al. 2004).

A city is considered to have shifted to an undesirable regime when experiencing a flood disaster involving widespread human, economic, and environmental changes that exceed the city's own ability to cope (United Nations International Strategy for Disaster Reduction 2004). The undesirable regime is characterized by significantly reduced resources and assets, large-scale population displacement, livelihood disruption, and loss of security (Adger 2000, Berkes et al. 2003). Once in it, moving to a better regime or developing a socioeconomic identity similar to the previous one is costly or impossible.

Essentially, urban resilience to floods is the capacity to avoid flood disaster. To prevent physical damage and socioeconomic disruption from occurring, it would depend on the city's floodability, which is defined here as the physical ability to accommodate-not resist-flooding. If damage and disruption had occurred, remaining in the regime counts on reorganization-reestablishment of socioeconomic order. While the return to preflood conditions is irrelevant, the speed of reorganization matters because prolonged socioeconomic disruption can eventually push the city into an undesirable regime (Walker and Westley 2011). Overall, urban resilience to floods is defined by floodability and reorganization, not flood resistance and recovery that engineering resilience would suggest.

Fig. 3. The tolerable range of socioeconomic state change dictates the shape or size of the basin of attraction that represents the desirable regime. A narrow range means a smaller, shallow basin (Case A), while a wider range leads to a larger, deeper basin (Case B).

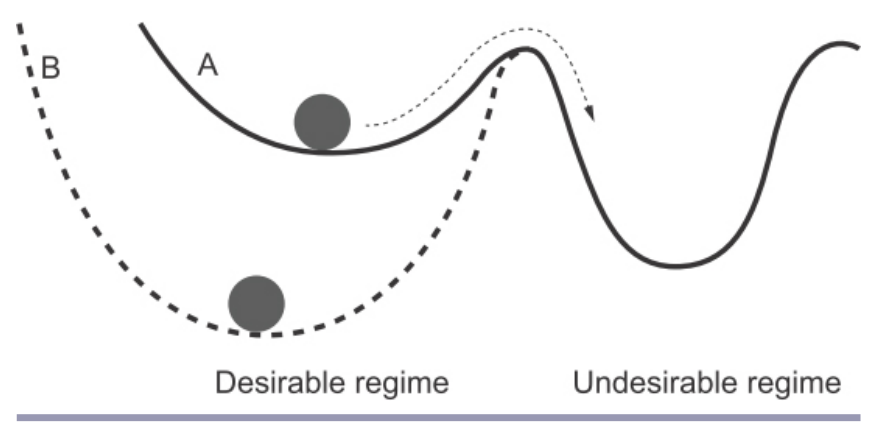

\section{Key properties}

Resilience is frequently associated with self-organization, adaptive capacity, and redundancy (Carpenter et al. 2001, Low et al. 2003, Tompkins and Adger 2004). Self-organizing systems are resilient to disturbances because of the distributed character (Heylighen 2001). Adaptive capacity can increase resilience over time, as it is associated with learning-the ability to adjust to changing internal demands and external 
conditions (Gunderson 2000, Carpenter and Brock 2008). Redundancy provides insurance against total system failure. These concepts can be translated into the following key properties of urban resilience to floods.

\section{Localized flood-response capacity}

Self-organizing cities, where each citizen and public manager could act immediately to avoid damage, are more agile in coping with flooding and are thus more resilient than cities that rely on centralized mechanisms such as flood-control infrastructure. If disrupted, they can also quickly reorganize because of the internal ability to clean up and fix damage without waiting for external help from the central government or aid agencies, which do not always act soon enough.

\section{Timely adjustments after every flood}

The adaptive capacity contributing to increasing urban resilience to floods is associated with the ability to learn from each flood, i.e., making timely behavioral, physical, and institutional adjustments to be better prepared for the next flood. Every flood entails something new, e.g., debris deposition at unexpected locations. By understanding new phenomena and making necessarily adjustments, the city incrementally increases floodability. It is a learning-by-doing process, where novelty is involved in the adaptation to avoid repeating the previous configuration (Walker et al. 2004, Adger 2006, Berkes 2007).

\section{Redundancy in subsystems}

Here, redundancy is more than duplication of the same element in an engineering sense, e.g., the freeboard added on top of the levee height required for confining a certain flow. It entails diversity and functional replication across scales (Peterson et al. 1998, Adger et al. 2005). For example, a water supply network with redundancy would incorporate both regional and localized systems and utilize different water sources. A flood hazard management system with redundancy would comprise a diversity of measures for mitigation, preparedness, response, and reorganization. The flood-response capacity would be distributed across the levels, i.e., individuals, communities, and the municipality, such that when the capacity of one level is overwhelmed, the city can still count on the others.

Underpinning the aforementioned three properties are diversity and flexibility. Short-term adjustments and longterm adaptation are impossible without a diversity of options to choose from (Folke et al. 2002, Davidson-Hunt and Berkes 2003). Diversity is particularly key to resilience because it enables adaptation by providing seeds for new opportunities (Berkes 2007). For example, a diverse economy or livelihood is known to facilitate reorganization after disasters (Berke and Campanella 2006). Flexibility allows the self-organizing city to preserve overall functionality during flooding by making immediate changes at smaller, faster scales in its subsystems (Allen et al. 2005). For example, if the public transportation system could quickly switch its service mode from land-based to waterborne when a flood occurs, it would ensure mobility to keep the city functional. Flexibility also promotes adaptive capacity, for rigidity prevents timely adjustments.

\section{Urban resilience to floods and urban river resilience}

Resilience of ecological systems plays an important role in human ability to cope with hazards. This is because it concerns the persistence of ecosystem services, the loss of which limits the options to adapt (Adger 2000, Berkes et al. 2003, Gunderson 2010). Ecosystem goods and services, such as fisheries and clean water, provided by rivers and other freshwater ecosystems are highly valuable (Costanza et al. 1997). While it is clear why ecosystem services are important to communities that are dependent on local resources for livelihoods (Adger et al. 2005), it is not obvious how resilience of local urban rivers relates to urban resilience to floods in modern cities. With significantly altered hydrology, geomorphology, biochemistry, and species composition, many urban rivers today are arguably already in sociallyecologically undesirable regimes, too degraded to offer ecosystem services (Paul and Meyer 2001, Groffman et al. 2003). Although drawing on services generated elsewhere buffers the impact of local declines, the degrading urban river still affects urban resilience to floods. Flooding of a polluted river increases damage and complicates reorganization; moreover, if a flood disrupts the imports of goods and services, the city would have no access to critical resources such as potable water. Resilience of urban rivers matters to urban resilience to floods as the ultimate insurance against the most socioeconomically disruptive floods.

\section{Urban resilience to floods and flood resistance}

Conventional wisdom assumes that flood resistance is necessary for cities; however, resilience theory suggests that it erodes urban resilience to floods (Holling and Meffe 1996). In effect, flood-control infrastructure puts the city in one or the other contrasting conditions: dry and stable, or inundated and disastrous. With flood-control infrastructure in place, flooding results exclusively from the infrastructure's failure and is more hazardous than if there were no flood-control infrastructure (Tobin 1995), such that the natural process of flooding becomes a synonym to disaster. Cities that are dependent on flood-control infrastructure are highly resistant - but not resilient- to floods because they have physically adapted to the artificially expanded dry-and-stable conditions to become intolerant of wet conditions (Fig. 4).

In cities that are dependent on flood-control infrastructure, the river's high flows are mostly confined between levees or held behind the upstream dam. The flood frequency is dramatically reduced and river dynamics are largely unnoticed. Each flood that is prevented is a loss of opportunity for learning (Klein et al. 1998, Colten and Sumpter 2009). Little flood experience leads to low awareness of flood risk among citizens (Correia et al. 1998), who are too accustomed to operating under the 
Fig. 4. A comparison between the resistant and resilient city. The resistant city is dependent on flood-control infrastructure, functioning only in the dry conditions and having little tolerance of socioeconomic state changes, i.e., narrow tolerable range. This leads to a small basin of attraction of the desirable regime, whose size is indicated by the shaded area; hence low urban resilience to floods. On the contrary, the resilient city tolerates flooding and much greater fluctuation in socioeconomic conditions, thus having a larger basin and consequentially greater urban resilience to floods.
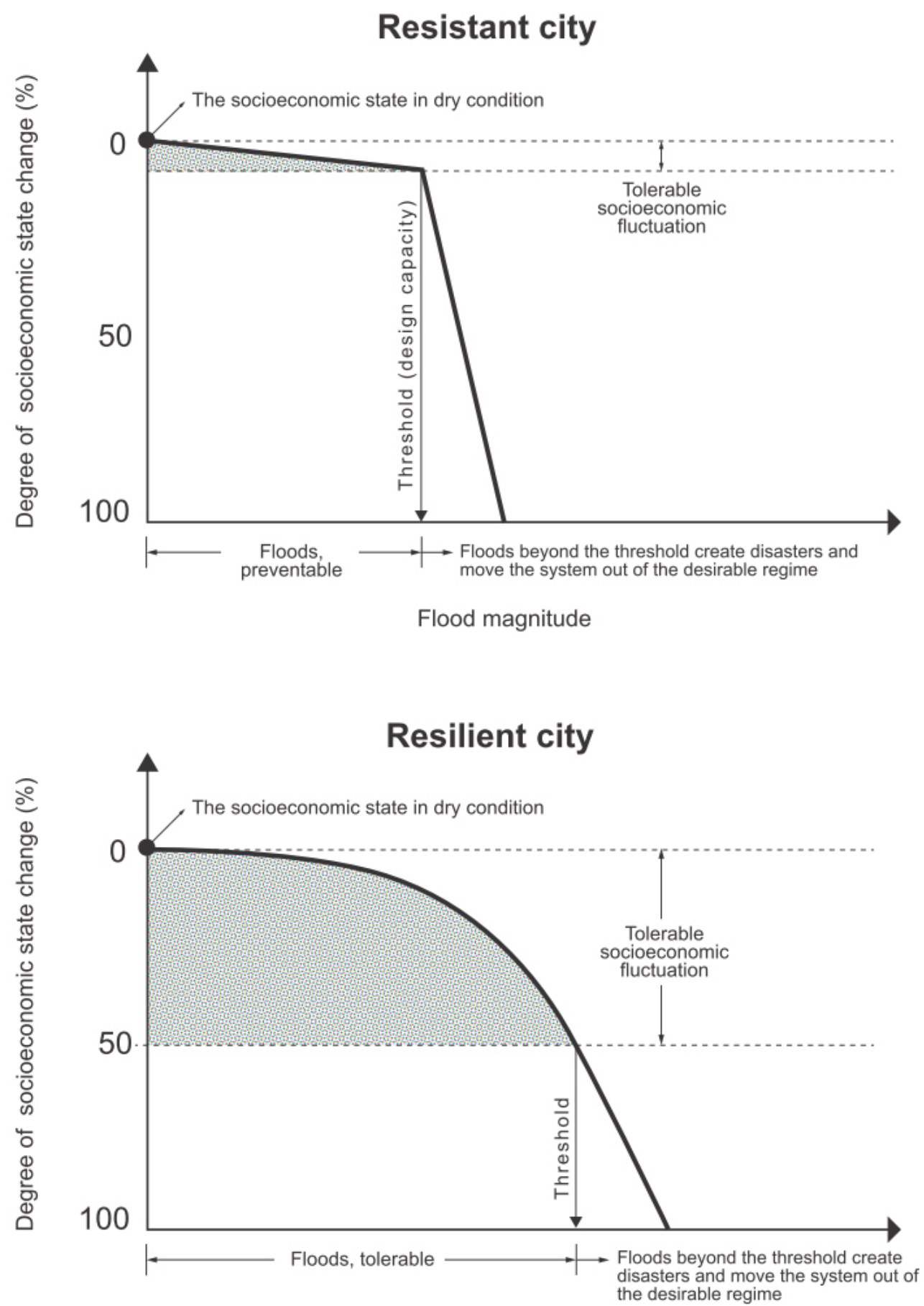

Flood magnitude 
dry-and-stable conditions, and know little about how to cope with inundation once the flood-control infrastructure fails. Furthermore, flood-control infrastructure's structural rigidity and large scope leave little flexibility for making timely adjustments to constantly changing boundary conditions (Pahl-Wostl 2002). The existence of flood-control infrastructure also prevents the development of a diversity of flood-coping measures because the development of such measures is too expensive (Castonguay 2007). Whereas floodcontrol infrastructure as a system may incorporate a diversity of engineering measures, each with structural redundancy, there is little diversity and cross-scale redundancy with regards to physical measures. Cities that are dependent on floodcontrol infrastructure tend to address only the river and not the built environment because flood-control infrastructure, as a centralized measure, creates a false sense of security that precludes the need for localized flood-response capacity.

As flood-control infrastructure erodes urban resilience to floods over time, a flood could easily cause high casualties and severe damage, complicate reorganization that relies heavily on external forces, and push the city to an undesirable regime, as was demonstrated in New Orleans after Hurricane Katrina in 2005 (Colten and Sumpter 2009). Flood-control infrastructure also decreases urban resilience to floods through its very function-i.e., prevention of periodic flooding. Periodic flooding is a critical mechanism to maintain the ecological functions and high biodiversity of floodplain rivers (Junk et al. 1989). The altered flood regime, with which native species are unfamiliar, affects the resilience of river ecosystems and contributes to system collapse (Poff et al. 1997, Folke 2003). Therefore, flood-control infrastructure compromises the river's ability to provide ecosystem services (Tockner et al. 2008), which in turn limits the city's options to adapt.

The argument that flood resistance erodes urban resilience to floods echoes the widely supported notion of risk transference, which holds that resistance to natural hazards is simply postponing them, only to build up risks and worsen disasters later (Etkin 1999, Mileti 1999). Because flood resistance compromises urban resilience to floods, persistence resulting from the flood being resisted-in effect no flood occursshould not be considered resilience.

\section{OPERATIONALIZING THE THEORY}

Turning theory into practice requires measuring urban resilience to floods. The growing interest in managing for social-ecological resilience has prompted research into methods for assessing potential resilience to future disturbances (e.g., Bennett et al. 2005, Cumming et al. 2005). Because resilience is not directly observable, it must be inferred from surrogates-forward-looking proxies for future resilience-although it is recognized that it is not possible to represent resilience with one surrogate alone (Carpenter et al. 2005).
Assessing urban resilience to floods requires surrogates for floodability and the capacity for quick reorganization. The former is addressed here. One way to find resilience surrogates for coupled human-natural systems is to look for the internal properties that alter resilience over time (Bennett et al. 2005). Slowly changing properties are often good candidates because they define the system's underlying structure, thus controlling the shape of the basin of attraction, threshold location, and system's position within the state space (Carpenter et al. 2001, Scheffer et al. 2001). For river cities, a property defining floodability would be one that reflects the physical and hydrologic changes of the floodplain, over which human interests conflict with flood processes to give rise to flood disasters.

\section{Functions of natural floodplains}

Floodplains are essentially a part of the river, which naturally function to convey and store the share of high flows and sediments that spill overbank. During large floods the amount of floodplain conveyance and storage is significantly greater than that of the channel (Leopold 1994). Floodplain storage occurs when the water is disconnected from the main channel flow and is slowly released after the peak has passed (Richards and Hughes 2008). Longer term storage takes place on the surface of floodplain wetlands and through infiltration into the floodplain soils, which can store large amounts of water during wet periods (Keddy 2000). Floodplain vegetation represents hydraulic roughness and exerts significant impacts on the flood process. For example, the overall patchiness increases the heterogeneity of flow patterns; dense vegetation dampens the flood wave and traps sediments during minor floods; the floodplain forest delays the release of floodwater stored on the surface though frictional effect, thus further enhancing floodplain storage (Tabacchi et al. 2000, Richards and Hughes 2008). Because of these hydrologic and hydraulic functions, floodplain rivers have lower flood peaks and velocities, and smaller flood discharges in downstream locations, compared to other types of rivers (Leopold 1994).

As a floodplain becomes urbanized, its functions are often replaced by artificially enhanced channel capacity, drainage efficiency, and upstream impoundment. At the same time, the river sees higher peak flows with increased downstream discharges (Criss and Shock 2001), leading to higher flood risk. The urbanized floodplain becomes less tolerant of flooding for there is less land functioning to convey and store floodwater and sediments.

\section{Floodable lands and percent floodable area}

To assess floodability, I propose a new concept - the floodable land-which is defined as a land capable of storing or conveying floodwater and sediments without incurring damage locally and elsewhere. Floodable lands can be of any land use and cover, thus not exclusively referring to undeveloped or green areas such as wetlands. A green area with contaminated soils, for example, would not be floodable; 
a residential lot with the building raised on poles may be. Floodable lands contribute to the city's flood tolerance, as a flood is benign where it is floodable. With a large combined area, floodable lands can lower flood peaks to reduce the overall flood impact. Everything else being equal, the more floodable lands the higher the floodability, which can be quantified by the percentage of the total area of floodable lands within the floodplain area, or percent floodable area. The floodplain area here refers to the entire valley floor between valley walls (Anderson et al. 1996). It is not defined by any flood recurrence interval because larger floods are always possible.

It is worth noting that with a percent floodable area of $100 \%$ a city could still be damaged by arare, extreme flood, in which case reorganization plays a major role in urban resilience to floods. I hypothesize a positive but nonlinear relationship between percent floodable area and floodability because at a higher percent floodable area its marginal contribution to floodplain storage and conveyance should decrease significantly (Douglas et al. 2007). I further hypothesize that there may be hysteresis involved in the relationship between percent floodable area and urban resilience to floods (Fig. 5), as seen in other complex systems (Scheffer et al. 2001, Alberti and Marzluff 2004). The city may have to "go back further" in reestablishing floodplain functions in order to shift to a regime where the city is resilient and able to self-organize to remain orderly during most floods, with a healthy urban river to provide ecosystem services. As a surrogate for urban resilience to floods, percent floodable area represents a city's physical fitness for flooding that matters to flood safety. Improving percent floodable area to build resilience can be a management approach that is an alternative to increasing the protection standard of flood-control infrastructure for enhancing resistance.

\section{RESILIENCE-BASED FLOOD HAZARD MANAGEMENT}

Enhancing resistance to one disturbance in complex adaptive systems often creates vulnerabilities to others (Holling and Meffe 1996, Roberge 2002). Flood control ignores complexity and unpredictability, exacerbating flood risk and creating ecological disasters. Today many cities are not flood-safe because they are premised on the artificial environmental stability that is forced by flood-control infrastructure and tolerate little socioeconomic fluctuation (Fig. 4). The management paradigm of control must be abandoned (Folke 2003, Anderies et al. 2006). For long-term flood safety, cities need to switch to resilience-based flood hazard management.

\section{Living with floods}

Resilience derives from living with disturbances (Gunderson 2000, Walker et al. 2004). Studies have shown that communities that are adapted, not resistant, to disturbances are long enduring (Berkes et al. 2003). Building urban
Fig. 5. The hypothetical dynamic of percent floodable area (PFA). During the process of floodplain urbanization (trajectory A), the city increasingly relies on flood control for flood safety, moving along the upper solid line and shifting dramatically at the threshold $\mathrm{T} 1(\mathrm{PFA}=\mathrm{X} 1)$ to the lower solid line. Passing T1, the floodplain has lost the natural functions to handle floodwater, and the city enters the regime where the river is degraded and the socioeconomic dynamics become disrupted and chaotic once a flood occurs. The city could move back to the regime where the river is healthy, and the city can self-organize to remain orderly during flooding by building resilience through increasing percent floodable area and decreasing the reliance on flood control. It is possible to significantly increase percent floodable area by making large and small open spaces multifunctional to convey and store floodwater during wet seasons, and by retrofitting existing buildings to be elevated, floatable, or wet-proofed. During the resiliencebuilding process (trajectory B), the city moves along the lower solid line, but reaching X1 is not sufficient to restore the same degree of resilience before the shift (T1). The city needs to go further, passing T2 (PFA > X2) in order to move back to the more resilient regime.

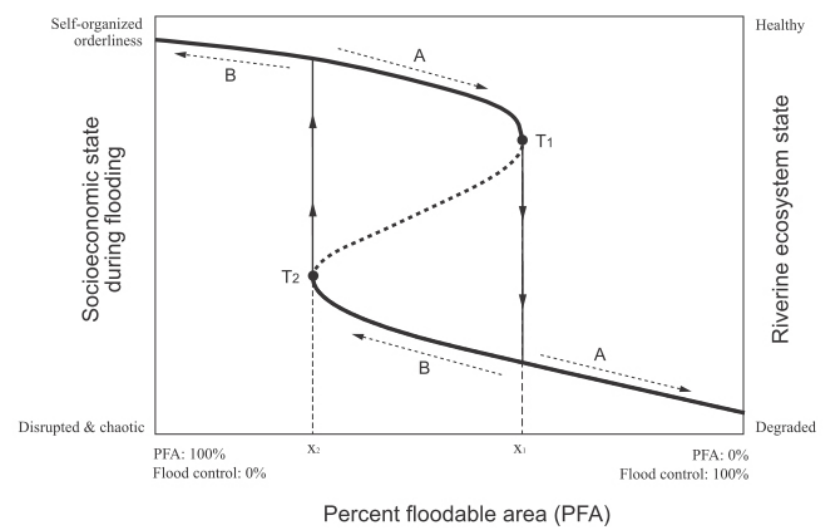

resilience to floods is essentially a process of adaptationinstead of fighting the river, cities live with periodic floods, allowing them to enter the city to learn from them, so as to become resilient to extreme ones. It is a paradigm shift from resistant to resilient cities with the management agenda redirected from "safety against floods" to "safety at floods" (Schielen and Roovers 2008). Urban resilience to floods lies in a principle that has long been called for-working with the river rather than against it (e.g., White 1945, Leopold 1977). It also echoes the ancient philosophy of "living with floods" that is still practiced today in rural communities in countries such as Bangladesh, Cambodia, and Egypt (Laituri 2000, Berkes 2007). Distinguishing between benign frequent floods 
and disastrous rare ones, these communities adapt lifestyles and built environments to river dynamics, harnessing the postflood productivity boosts in fisheries and agriculture (Cuny 1991).

Although relatively uncommon in the industrialized world, similar practices can be seen in management schemes that restore floodplain functions in rural areas to prevent downstream flooding, such as the Yolo Bypass for Sacramento River in the United States, the "Room for the River" project in the Netherlands, and the "Making Space for Water" policy in England (Moss and Monstadt 2008, Opperman et al. 2009). While at the watershed scale the notion of living with floods is increasingly accepted, it is dismissed in cities where lands are deemed culturally and economically too valuable to be inundated. That cities and floods are incompatible is an entrenched perception, further enhanced by the argument that retreating from floodplains is the fundamental solution to flood hazards. Although logical, this prohibitionist discourse can close down options and prevent creative solutions (Antrobus 2010). Because retreat is politically difficult in highly populated areas and people intuitively assume there is no room for flooding, cities have no choice but to continue relying on flood-control infrastructure. However, cities are too valuable to reject the paradigm shift to live with floods in order to survive.

\section{Flood adaptation}

The assertion that cities and floods cannot coexist shows a lack of imagination, resulting from being too accustomed to the kind of built environment not adapted to floods. With a shift in perception and creative planning and design, cities can eventually phase out flood-control infrastructure and live with floods by retrofitting the built environment and adding redundancy, diversity, and flexibility into every subsystem. Open spaces can become multifunctional to convey and store floodwater during wet seasons (Douglas et al. 2007). Infrastructure can be redesigned into a collection of diverse functional elements that are flexible in operation (Fiering 1982). Buildings can be remodeled to be elevated, floatable, or wet-proofed (Guikema 2009).

It would require a change in city design. An initiative called "Water Sensitive Cities" is unfolding to integrate water management into urban planning and design to promote resilience to climate change (Howe and Michell 2012), with Rotterdam being a notable example of flood adaptation (Jacobs 2012). But a paradigm shift in city design is also necessary-it should be based on dynamism instead of presumed environmental stability. Floodplains are constantly changing, rearranged not only by inundation but also by channel migration in which land could become the site of a flowing river and vice versa. Forgoing stability and perpetuity, building structures that are adaptive, removable, and temporary are the most realistic way to live on floodplains.
Flood adaptation as the mitigation approach would correct several problems induced by flood control. First, it would not transfer the city's own problem elsewhere, as levees and channelization do by reducing floodplain retention and increasing flow velocity to increase downstream flooding, and as flood-control dams do by submerging upstream areas to displace people. Second, it would not increase long-term flood risk, as there is no threat of flood-control infrastructure failure, through which damages by larger floods would be more catastrophic than if there were no flood-control infrastructure (Tobin 1995). Third, it would not conflict with, but rather could reconcile with ecological preservation and restoration of urban rivers by allowing ecologically critical periodic floods to reconnect the channel and floodplain (Nienhuis and Leuven 2001). Resilience-based management supports the recovery of river health because the ability of the river to provide ecosystem services promotes urban resilience to floods.

The process of incorporating change continuously gives rise to resilience (Holling 1986). Therefore, resilience-based management is itself adaptive and a learning-by-doing process, where specific objectives are open to adjustment after each flood. In resilient cities, the built environment is adaptive in two ways: it is fit for known river dynamics based on historic patterns; it is also easily adjustable to changing boundary conditions, such as climate change and population growth. The resilient city is always a work in progress.

\section{Redefining the norm}

Managing resilience is an agenda of multiple scales, because resilience is controlled by dynamics at scales above and below the scale of the system in question (Walker et al. 2004, Anderies et al. 2006). The city's subsystems affect urban resilience to floods by controlling its position in the basin of attraction. Compare different mitigation approaches for example: flood control places the city very close to the threshold between desirable and undesirable regimes during high flows, because the city tolerates little inundation; whereas flood adaptation places the city further away. Other internal factors that affect urban resilience to floods includes river health, economic status of households, institutional flexibility, design and operation of buildings and critical infrastructure, crisis support network, etc. The subsystems are simultaneously influenced by economic, cultural, biophysical, and climatic dynamics at regional and even global scales, which change the shape of the basin of attraction to affect urban resilience to floods. Managing for urban resilience to floods thus requires attending to these cross-scale interactions.

A large-scale factor critically affecting urban resilience to floods is the norm of socioeconomic dynamics. Cities that are dependent on flood-control infrastructure are nonresilient not only because they are too close to the threshold but also because the current desirable regime is small/shallow (Fig. 3), 
resulting from little tolerance of socioeconomic fluctuation (Fig. 4). The norm in modern society is the execution of unabated socioeconomic activities, such that when a flood occurs and goods and services are not produced it is called economic loss, and that when mobility is limited by a flood it is considered inconvenient. However, the ideology that the same socioeconomic activities should be carried out continuously is built on the premise of environmental stability, the maintenance of which is likely to be more difficult because extreme storm events are expected to increase with climate change (Alley et al. 2007). As environmental stability becomes uncertain, the best strategy to remain in the desirable regime is to enlarge the regime itself (Carpenter et al. 2001). Because the boundary of desirable regime is socially constructed, expanding it involves redefining the norm-society needs to accept necessary changes in the form and intensity of socioeconomic activities, because the supporting infrastructure, even if adaptive to flooding, may still be limited by it. It does not mean accepting system failure during flooding, rather it implies socioeconomic flexibility and adaptability. This would involve a worldview change away from the obsession of stability (Folke 2003).

\section{CONCLUSION}

With growing popularity, the term resilience is increasingly used vaguely such that it is becoming like the word sustainability, i.e., having a diluted and unclear meaning (Brand and Jax 2007). Without a rigorous definition and some form of measurement, resilience would not be a useful concept for practice (Manyena 2006). This paper presents a comprehensive theory of urban resilience that embraces inherent dynamism and uncertainties to provide unconventional perspectives for coping with flood hazards. It addresses the issue of extreme floods, which cannot be neglected any longer. The theory suggests flood adaptation, and it challenges the conventional wisdom that cities cannot live without flood control. The development of the theory of urban resilience to floods is an attempt to enrich the existing body of resilience theory through focusing on a specific type of system with a specific problem. Research on resilience associated with human-nature couplings is still in an explorative stage with few practical methods for real-world applications (Carpenter et al. 2005, Folke 2006). The theory of urban resilience to floods, along with the surrogate measure of percent floodable area for assessing floodability, helps facilitate the application of field-based, interdisciplinary research.

The immediate real-world challenge, however, is not how to increase urban resilience to floods but how to catalyze the transformation from resistant to resilient cities. A daunting problem is that the current management regime of flood control is itself very resilient. While disasters can be catalysts for social transformation (Pelling and Dill 2010), transforming by choice is much less costly. It requires transformabilitythe capacity to create a fundamentally new system, about which we know much less than what makes a system resilient (Walker et al. 2004, Pelling and Manuel-Navarrete 2011). The move towards creating resilient cities is a research frontier.

Responses to this article can be read online at: http://www.ecologyandsociety.org/issues/responses. $\mathrm{php} / 5231$

\section{Acknowledgments:}

I thank Marina Alberti, Robert Mugerauer, and Robert J. Naiman of the University of Washington, Seattle, Washington, USA; Christopher P. Konrad of the U.S. Geological Society (USGS), Northwest Area, Tacoma, Washington, USA; and two anonymous reviewers for their valuable comments that helped to improve this paper.

\section{LITERATURE CITED}

Adger, W. N. 2000. Social and ecological resilience: are they related? Progress in Human Geography 24(3):347-364.

Adger, W. N. 2006. Vulnerability. Global Environmental Change 16:268-281. http://dx.doi.org/10.1016/j.

gloenvcha.2006.02.006

Adger, W. N., T. P. Hughes, and C. Folke, S. R. Carpenter, and J. Rockström. 2005. Social-ecological resilience to coastal disasters. Science 309:1036-1039. http://dx.doi. org/10.1126/science. 1112122

Alberti, M., and J. M. Marzluff. 2004. Ecological resilience in urban ecosystems: linking urban patterns to human and ecological functions. Urban Ecosystems 7 (3):241-265. http:// dx.doi.org/10.1023/B:UECO.0000044038.90173.c6

Allen, C. R., L. Gunderson, and A. R. Johnson. The use of discontinuities and functional groups to assess relative resilience in complex systems. Ecosystems 8:985-966.

Alley, R. B., T. Berntsen, N. L. Bindoff, Z. Chen, A. Chidthaisong, P. Friedlingstein, J. M. Gregory, G. C. Hegerl, M. Heimann, B. Hewitson, B. J. Hoskins, F. Joos, J. Jouzel, V. Kattsov, U. Lohmann, M. Manning, T. Matsuno, M. Molina, N. Nicholls, J. Overpeck, D. Qin, G. Raga, V. Ramaswamy, J. Ren, M. Rusticucci, S. Solomon, R. Somerville, T. F. Stocker, P. A. Stott, R. J. Stouffer, P. Whetton, R. A. Wood, and D. Wratt. 2007. Summary for policymakers. In S. Solomon, D. Qin, M. Manning, Z. Chen, M. Marquis, K. B. Averyt, M. Tignor, H. L. Miller, editors. Climate change 2007: the physical science basis. Contribution of Working Group I to the fourth assessment report of the Intergovernmental Panel on Climate Change. Cambridge University Press, Cambridge, UK and New York, USA. 
Anderies, J. M., B. H. Walker, and A. P. Kinzig. 2006. Fifteen weddings and a funeral: case studies and resilience-based management. Ecology and Society 11(1):21. [online] URL: http://www.ecologyandsociety.org/vol11/iss1/art21/.

Anderson, M. G., D. R. Walling, and P. Bates, editors. 1996. Floodplain processes. John Wiley \& Sons, Chichester, UK. http://dx.doi.org/10.1080/11035890401263279

Antrobus, D. 2010. The importance of the "not-so-cool" sectors: creative solutions to reconcile environmental and economic sustainability within a floodplain. Local Environment 15(4):295-308. http://dx.doi.org/10.2307/951696

Associated Programme on Flood Management. 2009. Integrated flood management concept paper. World Meteorological Organization, Geneva, Switzerland.

Bennett, E. M., G. S., Cumming, and G. D. Peterson. 2005. A system model approach to determining resilience surrogates for case studies. Ecosystems 8:945-957. http://dx.doi. org/10.1007/s10021-005-0141-3

Berke, P. R., and T. J. Campanella. 2006. Planning for postdisaster resiliency. Annals of the American Academy of Political and Social Science 604:192. http://dx.doi. org/10.1177/0002716205285533

Berkes, F. 2007. Understanding uncertainty and reducing vulnerability: lessons from resilience thinking. Natural Hazards 41(2):283-295. http://dx.doi.org/10.1007/s11069-006-9036-7

Berkes, F., J. Colding, and C. Folke, editors. 2003. Navigating social-ecological systems: building resilience for complexity and change. Cambridge University Press, Cambridge, UK.

Berkes, F., and C. Folke, editors. 1998. Linking social and ecological systems: management practices and social mechanisms for building resilience. Cambridge University Press, Cambridge, UK.

Birkland, T. A., R. J. Burby, D. Conrad, H. Cortner, and W. K. Michener. 2003. River ecology and flood hazard mitigation. Natural Hazards Review 4(1):46-54. http://dx.doi.org/10.1061/(ASCE) $\underline{1527-6988(2003) 4: 1(46)}$

Birkland, T. A., and S. Waterman. 2009. The politics and policy challenges of disaster resilience. Pages 15-38 in C. P. Nemeth, E. Hollnagel, and S. Dekker, editors. Resilience engineering perspectives. Volume 2: preparation and restoration. Ashgate Publishing Limited, Surrey, UK.

Bosher, L. 2008. Introduction: the need for built-in resilience. Pages 3-19 in L. S. Bosher, editor. Hazards and the built environment: attaining built-in resilience. Taylor and Francis, London, UK.

Brand, F. S., and K. Jax. 2007. Focusing the meaning(s) of resilience: resilience as a descriptive concept and a boundary object. Ecology and Society 12(1):23. [online] URL: http:// www.ecologyandsociety.org/vol12/iss1/art23/.

Bruneau, M., S. E. Chang, R. T. Eguchi, G. C. Lee, T. D. O'Rourke, A. M. Reinhorn, M. Shinozuka, K. Tierney, W. A. Wallace, and D. von Winterfeldt. 2003. A framework to quantitatively assess and enhance the seismic resilience of communities. Earthquake Spectra 19(4):733-752.

Burby, R. J., R. E., Deyle, D. R. Godschalk, and R. B. Olshansky. 2000. Creating hazard resilient communities through land-use planning. Natural Hazards Review 1 (2):99-106. http://dx.doi.org/10.1061/(ASCE)1527-6988(2000) 1:2(99)

Carpenter, S. R., and W. A. Brock. 2008. Adaptive capacity and traps. Ecology and Society 13(2):40. [online] URL: http:// www.ecologyandsociety.org/vol13/iss2/art40/.

Carpenter, S. R., B. Walker, J. M. Anderies, and N. Abel. 2001. From metaphor to measurement: resilience of what to what? Ecosystems 4 (8):765-781.

Carpenter, S. R., F. Westley, and M. Turner. 2005. Surrogates for resilience of social-ecological systems. Ecosystems 8:941-944. http://dx.doi.org/10.1007/s10021-005-0170-y

Castonguay, S. 2007. The production of flood as natural catastrophe: extreme events and the construction of vulnerability in the drainage basin of the St. Francis River (Quebec), mid-nineteenth to mid-twentieth century. Environmental History 12:820-844. http://dx.doi.org/10.1093/ envhis/12.4.820

Colten, C. E., and A. R. Sumpter. 2009. Social memory and resilience in New Orleans. Natural Hazards 48(3):355-364. http://dx.doi.org/10.1007/s11069-008-9267-x

Correia, F. N., M. Fordham, D. G. Saraiva, and F. Bernado. 1998. Flood hazard assessment and management: interface with the public. Water Resources Management 12(3):209227.

Costanza, R., R. d'Arge, R. de Groot, S. Farber, M. Grasso, B. Hannon, K. Limburg, S. Naeem, R. V. O'Neill, J. Paruelo, R. G. Raskin, P. Sutton, and M. van den Belt. 1997. The value of the world's ecosystem services and natural capital. Nature 387:253-260. http://dx.doi.org/10.1038/387253a0

Criss, R. E., and E. L. Shock. 2001. Flood enhancement through flood control. Geology 29(10):875-873. http://dx.doi. org/10.1130/0091-7613(2001)029<0875:FETFC >2.0.CO;2

Cumming, G. S., G. Barnes, S. Perz, M. Schmink, K. E. Sieving, J. Southworth, M. Binford, R. D. Holt, C. Stickler, and T. van Holt. 2005. An exploratory framework for the empirical measurement of resilience. Ecosystems 8:975-987. http://dx.doi.org/10.1007/s10021-005-0129-Z 
Cumming, G. S., D. H. M. Cumming, and C. L. Redman. 2006. Scale mismatches in social-ecological systems: causes, consequences, and solutions. Ecology and Society 11(1):14. [online] URL: http://www.ecologyandsociety.org/vol11/iss1/ art14/.

Cuny, F. C. 1991. Living with floods: alternatives for riverine flood mitigation. Land Use Policy 8(4):331-342.

Davidson-Hunt, I., and F. Berkes. 2003. Nature and society through the lens of resilience: toward a human-in-ecosystem perspective. Pages 53-82 in F. Berkes, J. Colding, and C. Folke. Navigating social-ecological systems: building resilience for complexity and change. Cambridge University Press, Cambridge, UK. http://dx.doi.org/10.1017/

\section{CBO9780511541957.006}

De Bruijn, K. M. 2004. Resilience indicators for flood risk management systems of lowland rivers. International Journal of River Basin Management 2(3):199-210. http://dx.doi. org/10.1080/15715124.2004.9635232

Douglas, I., M. Kobold, N. Lawson, E. Pasche, and I. White. 2007. Characterisation of urban streams and urban flooding. Pages 29-58 in R. Ashley, S. Garvin, E. Pasche, A. Vassilopoulos, and C. Zevenbergen, editors. Advances in urban flood management. Taylor \& Francis, New York, New York, USA. http://dx.doi.org/10.1201/9780203945988.ch3

Etkin, D. 1999. Risk transference and related trends: driving forces towards more mega-disasters. Environmental Hazards 1:69-75. http://dx.doi.org/10.3763/ehaz.1999.0109

Fiering, M. B. 1982. Alternative indices of resilience. Water Resources Research 18(1):33-39. http://dx.doi.org/10.1029/ WR018i001p00033

Folke, C. 2003. Freshwater for resilience: a shift in thinking. Philosophical Transactions of the Royal Society of London: Series B Biological Sciences 358(1440):2027-2036. http://dx. doi.org/10.1098/rstb.2003.1385

Folke, C. 2006. Resilience: the emergence of a perspective for social-ecological systems analyses. Global Environmental Change 16:253-267. http://dx.doi.org/10.1016/j.

gloenvcha.2006.04.002

Folke, C., S. Carpenter, T. Elmqvist, L. Gunderson, C. S. Holling, and B. Walker. 2002. Resilience and sustainable development: building adaptive capacity in a world of transformations. Ambio 31(5):437-440.

Groffman, P. M., D. J. Bain, L. E. Band, K. T. Belt, G. S. Brush, J. M. Grove, R. V. Pouyat, I. C. Yesilonis, and W. C. Zipperer. 2003. Down by the riverside: urban riparian ecology. Frontiers in Ecology and the Environment 1(6):315-321.

Godschalk, D. R. 2003. Urban hazard mitigation: creating resilient cities. Natural Hazards Review 4(3):136-143. http:// dx.doi.org/10.1061/(ASCE)1527-6988(2003)4:3(136)
Guikema, S. D. 2009. Infrastructure design issues in disasterprone-regions. Science 323:1302-1303. http://dx.doi.org/10.1126/ $\underline{\text { science. } 1169057}$

Gunderson, L. H. 2000. Ecological resilience-in theory and application. Annual Review of Ecology and Systematics 31:425-439. http://dx.doi.org/10.1146/annurev.ecolsys.31.1.425

Gunderson, L. H. 2010. Ecological and human community resilience in response to natural disasters. Ecology and Society 15(2):18. [online] URL: http://www.ecologyandsociety.org/ vol15/iss $2 / \operatorname{art} 18 /$.

Gunderson, L. H., and C. S. Holling, editors. 2002. Panarchy: understanding transformations in human and natural systems. Island Press, Washington D.C., USA.

Hashimoto, T., J. R. Stedinger, and D. P. Loucks. 1982. Reliability, resiliency, and vulnerability criteria for water resource system performance evaluation. Water Resources Research 18(1):14-20. http://dx.doi.org/10.1029/WR018i001p00014

Heylighen, F. 2001. The science of self-organization and adaptivity. L.D. Kiel, editor. Knowledge management, organizational intelligence and learning, and complexity. The Encyclopedia of Life Support Systems. Eolss Publishers, Oxford, UK.

Holling, C. S. 1973. Resilience and stability of ecological systems. Annual Review of Ecology and Systematics 4:1-23. http://dx.doi.org/10.1146/annurev.es.04.110173.000245

Holling, C. S. 1986. The resilience of terrestrial ecosystems: local surprise and global change. Pages 292-317 in W. C. Clark and R. E. Munn, editors. Sustainable development of the biosphere. Cambridge University Press, Cambridge, UK.

Holling, C. S. 1996. Engineering resilience versus ecological resilience. Pages 31-43 in P. C. Schulze, editor. Engineering within ecological constraints. National Academy Press, Washington D.C., USA.

Holling, C. S., L. H. Gunderson, and G. D. Peterson. 2002. Sustainability and panarchies. Pages 63-102 in L. H. Gunderson and C. S. Holling, editors. Panarchy: understanding transformations in human and natural systems. Island Press, Washington D.C., USA.

Holling C. S., and G. K. Meffe. 1996. Command and control and the pathology of natural resource management. Conservation Biology 10 (2):328-37. http://dx.doi.org/10.1046/ j.1523-1739.1996.10020328.x

Hollnagel, E., C. P. Memeth, and S. Dekker, editors. 2008. Resilience engineering perspectives. volume 1: remaining sensitive to the possibility of failure. Ashgate, Burlington, Vermont, USA.

Howe, C., and C. Mitchell, editors. 2012. Water Sensitive Cities. IWA Publishing, London, UK. 
Jacobs, J. C. J. 2012. The Rotterdam approach: connecting water with opportunities. Pages 251-263 in C. Howe and C. Mitchell, editors. Water Sensitive Cities. IWA Publishing, London, UK.

Junk, W. J., P. B. Bayley, and R. E. Sparks. 1989. The flood pulse concept in river-floodplain systems. Special Publication of the Canadian Journal of Fisheries and Aquatic Sciences 106:110-127.

Keddy, P. A. 2000. Wetland ecology: principles and conservation. Cambridge University Press, Cambridge, UK.

Klein, R. J. T., R. J. Nicholls, and F. Thomalla. 2003. Resilience to natural hazards: how useful is this concept? Environmental Hazards 5:35-45.

Klein, R. J. T., M. J. Smit, H. Goosen, and C. H. Hulsbergen. 1998. Resilience and vulnerability: coastal dynamics or Dutch dikes? The Geographical Journal 164 (3):259-268.

Laituri, M. J. 2000. Cultural perspectives of flooding. Pages 451-468 in E. E. Wohl, editor. Inland flood hazards: human, riparian, and aquatic communities. Cambridge University Press, Cambridge, UK. http://dx.doi.org/10.1017/ CBO9780511529412.018

Leopold, L. B. 1977. A reverence for rivers. Geology 5:429-430. http://dx.doi.org/10.1130/0091-7613(1977)5<429: ARFR>2.0.CO;2

Leopold, L. B. 1994. Flood hydrology and the floodplain. Water Resources Update 95:11-15.

Liu, J., T. Dietz, S. R. Carpenter, M. Alberti, C. Folke, E. Moran, A. N. Pell, P. Deadman, T. Kratz, J. Lubchenco, E. Ostrom, Z. Ouyang, W. Provencher, C. L. Redman, S. H. Schneider, and W. W. Taylor. 2007. Complexity of coupled human and natural systems. Science 317:1513-1516. http://dx. doi.org/10.1126/science.1144004

López-Marrero, T., and P. Tschakert. 2011. From theory to practice: building more resilient communities in flood-prone areas. Environment \& Urbanization 23(1):229-249. http://dx. doi.org/10.1177/0956247810396055

Low, B., E. Ostrom, C. Simon, and J. Wilson. 2003. Redundancy and diversity: do they influence optimal management? Pages 83-114 in F. Berkes, J. Colding, and C. Folke. Navigating social-ecological systems: building resilience for complexity and change. Cambridge University Press, Cambridge, UK.

Manyena, S. B. 2006. The concept of resilience revisited. Disasters 30(4):433-450. http://dx.doi.org/10.1111/ j.0361-3666.2006.00331.x

Mileti, D. S. 1999. Disasters by design: a reassessment of natural hazards in the United States. Joseph Henry Press, Washington D.C., USA.
Milly, P. C. D., J. Betancourt, M. Falkenmark, R. M. Hirsch, Z. W. Kundzewicz, D. P. Lettenmaier, and R. J. Stouffer. 2008. Stationarity is dead: whither water management? Science 319:573-574.

Moss, T., and J. Monstadt, editors. 2008. Restoring floodplains in Europe: policy contexts and project experiences. IWA Publishing, London, UK.

Nienhuis, P. H., and R. S. E. W. Leuven. 2001. River restoration and flood protection: controversy or synergism? Hydrobiologia 444:85-89.

Opperman, J. J., G. E. Galloway, J. Fargione, J. F. Mount, B. D. Richter, and S. Secchi. 2009. Sustainable floodplains through large-scale reconnection to rivers. Science 326:1487-1488. http://dx.doi.org/10.1126/science.1178256

Pahl-Wostl, C. 2002. Towards sustainability in the water sector-the importance of human actors and processes of social learning. Aquatic Sciences 64:394-411. http://dx.doi. org/10.1007/PL00012594

Paul, M. J., and J. L. Meyer. 2001. Streams in the urban landscape. Annual Review of Ecology \& Systematics 32:333-365.

Pelling, M. 2003. Vulnerability of Cities: Natural Disasters and Social Resilience. Earthscan Publications, London, UK.

Pelling, M., and C. Dill. 2010. Disaster politics: tipping points for change in the adaptation of sociopolitical regimes. Progress in Human Geography 34:21-37. http://dx.doi. org/10.1177/0309132509105004

Pelling, M., and D. Manuel-Navarrete. 2011. From resilience to transformation: the adaptive cycle in two Mexican urban centers. Ecology and Society 16(2):11. [online] URL: http:// www.ecologyandsociety.org/vol16/iss2/art11/.

Peterson G., C. R. Allen, and C. S. Holling. 1998. Ecological resilience, biodiversity, and scale. Ecosystems 1:6-18. http:// dx.doi.org/10.1007/s100219900002

Poff, N. L., J. D. Allan, M. B. Bain, J. R. Karr, K. L. Prestegaard, B. D. Richter, R. E. Sparks, and J. C. Stromberg. 1997. The nature flow regime: a paradigm for river conservation and restoration. BioScience 47 (11):769-784.

Richards, K., and F. Hughes. 2008. Floodplains in Europe: the case for restoration. Pages 16-43 in T. Moss, and J. Monstadt, editors. Restoring floodplains in Europe: policy contexts and project experiences. IWA publishing, London, UK.

Roberge, M. 2002. Human modification of the geomorphically unstable Salt River in metropolitan Phoenix. The Professional Geographer 54(2):175-189. http://dx.doi.org/10.1111/0033-0124.00324 
Scheffer, M., S. Carpenter, J. A. Foley, C. Folke, and B. Walker. 2001. Catastrophic shifts in ecosystems. Nature 413 (11):591-596. http://dx.doi.org/10.1016/j.tree.2003.09.002

Scheffer, M., S. H. Hosper, M-L. Meijer, B. Moss, and E. Jeppesen. 1993. Alternative equilibria in shallow lakes. Trends in Ecology and Revolution 8(8):275-279. http://dx.doi. org/10.1016/0169-5347(93)90254-M

Schielen, R. M. J., and G. Roovers. 2008. Adaptation as a way for flood management. Proceedings of the $4^{\text {th }}$ International Symposium on Flood Defence: Managing Flood Risk, Reliability and Vulnerability May 6-8, 2008, Toronto, Ontario, Canada.

Schneidergruber, M., M. Cierna, and T. Jones. 2004. Living with floods: achieving ecologically sustainable flood management in Europe. WWF European Policy, Brussels, Belgium.

Smit, B., and J. Wandel. 2006. Adaptation, adaptive capacity and vulnerability. Global Environmental Change 16:282-292. http://dx.doi.org/10.1016/j.gloenvcha.2006.03.008

Smits, A. J. M., P. H. Nienhuis, and H. L. F. Saeijs. 2006. Changing estuaries, changing views. Hydrobiologia 565:339-355. http://dx.doi.org/10.1007/s10750-005-1924-4

Tabacchi, E., L. Lambs, H. Guiloy, A. Planty-Tacacchi, E. Muller, and H. Décamps. 2000. Impacts of riparian vegetation on hydrological processes. Hydrological Processes 14:2959-2976. http://dx.doi.org/10.1002/1099-1085(200011/12) 14:16/17<2959::AID-HYP129>3.0.CO;2-B

Tobin, G. A. 1995. The levee love affair: a stormy relationship? Water Resources Bulletin 31(3):359-367.

Tobin, G. A. 1999. Sustainability and community resilience: the holy grail of hazards planning? Environmental Hazards $1: 13-25$.

Tockner, K., S. E. Bunn, C. Gordon, R. J. Naiman, G. P. Quinn, and J. A. Standford. 2008. Flood plains: critically threatened ecosystems. Pages 45-61 in N. V. C. Polunin, editor. Aquatic ecosystems. Cambridge University Press, Cambridge, UK. http://dx.doi.org/10.1017/CBO9780511751790.006

Tompkins, E. L., and W. N. Adger. 2004. Does adaptive management of natural resources enhance resilience to climate change? Ecology and Society 9(2):10. [online] URL: http:// www.ecologyandsociety.org/vol9/iss2/art10/.

United Nations International Strategy for Disaster Reduction. 2004. Living with Risk: A Global Review of Disaster Reduction Initiatives. United Nations, New York, New York, USA.

Vale, L. J., and T. J. Campanella, editors. 2005. The resilient city: how modern cities recover from disaster. Oxford University Press, Oxford, UK.
Walker, B., C. S. Holling, S. R. Carpenter, and A. Kinzig. 2004. Resilience, adaptability and transformability in socialecological systems. Ecology and Society 9(2):5. [online] URL: http://www.ecologyandsociety.org/vol9/iss2/art5/.

Walker, B., and F. Westley. 2011. Perspectives on resilience to disasters across sectors and cultures. Ecology and Society 16(2):4. [online] URL: http://www.ecologyandsociety.org/ vol16/iss $2 / \operatorname{art} 4 /$.

Wang. C., and J. M. Blackmore. 2009. Resilience concepts for water resource systems. Journal of Water Resources Planning and Management 135(6):528-536. http://dx.doi.org/10.1061/(ASCE) 0733-9496(2009)135:6(528)

White, G. F. 1945. Human adjustment to floods: a geographical approach to the flood problem in the United States. Department of Geography, University of Chicago, Chicago, Illinois, USA.

Zevenbergen, C., and B. Gersonius. 2007. Challenges in urban flood management. Pages 1-11 in R. Ashley, S. Garvin, E. Pasche, A. Vassilopoulos, and Zevenbergen, editors. Advances in urban flood management. Taylor \& Francis, New York, New York, USA. http://dx.doi.org/10.1201/9780203945988. $\underline{\mathrm{ch} 1}$ 